\title{
Learning at Home During the Covid-19 Pandemic by Optimizing Video Based Tutorials
}

\author{
Belajar di Rumah Selama Pandemi Covid-19 dengan Mengoptimalkan Tutorial \\ Berbasis Video
}

\author{
Received: \\ 1 December 2020 \\ Revised: \\ 22 July 2021 \\ Published: \\ 8 August 2021
}

\author{
1*Muhammad Sholeh, ${ }^{2}$ Suraya, ${ }^{3}$ Dina Andayani \\ 1,2,3, Informatika, Institut Sains \& Teknologi AKPRIND Yogyakarta \\ ${ }^{1,2,3}$ Yogyakarta, Indonesia \\ E-mail: ${ }^{1}$ muhash@akprind.ac.id, ${ }^{2}$ suraya@akprind.ac.id, \\ 32ina_asnawi@yahoo.com \\ *Corresponding Author
}

\begin{abstract}
The learning process carried out at home during the COVID-19 pandemic demands the creativity of educators so that the material provided can be understood by students. The problems that arise during online lectures are changing the habits of students who always get detailed explanations from lecturers, while in online lectures the interaction between students and lecturers is limited and there are student guidelines for independent study. The research was conducted with the aim of evaluating the learning process at home using video-based tutorials. The methodology is carried out using the ADIIE model. The process of making tutorials is done by making a video story board that will be made and implementing the story board using Camtasia Studio. The results of the study resulted in Structured Programming course material in the form of video tutorials from meetings 1 to 10 . The evaluation results showed that $39.1 \%$ of students answered very well to the question of whether videos can be used for selfstudy at home and $60.8 \%$ answered quite well.
\end{abstract}

Keyword - Pandemic, Covid-19, Video Tutorial, Structured Programming

Abstrak-Proses pembelajaran yang dilakukan di rumah selama pandemi covid 19 menuntut kreativitas pendidik agar materi yang diberikan dapat dipahami oleh peserta didik. Permasalahan yang muncul selama dalam kuliah online adalah mengubah kebiasaan mahasiswa yang selalu mendapatkan penjelasan secara detail dari dosen, sementara dalam kuliah online interaksi antara mahasiswa dan dosen terbatas dan ada tuntunan mahasiswa untuk belajar secara mandiri. Penelitian dilakukan dengan tujuan untuk mengevaluasi proses pembelajar di rumah dengan menggunakan tutorial berbasis video. Metodologi yang dilakukan dengan menggunakan model ADIIE. Proses pembuatan tutorial dilakukan dengan membuat story board video yang akan dibuat dan implementasi story board menggunakan Camtasia Studio. Hasil penelitian menghasilkan materi mata kuliah Pemrograman Terstruktur berupa tutorial video dari pertemuan 1 sampai 10. Hasil evaluasi menunjukkan, 39,1\% mahasiswa menjawab sangat baik untuk pertanyaan apakah video dapat dipergunakan untuk belajar sendiri di rumah dan 60,8\% menjawab cukup baik.

Kata Kunci-Pandemi, Covid-19, Tutorial video, Pemrograman Terstruktur 


\section{INTRODUCTION}

People can quickly get tutorial materials in today's technological era, both book-based and in video form. YouTube support makes it easier for people to learn the material. Content on YouTube makes the learning process easier. Although many contents can be accessed and used as learning media, it must not depend on the existing content on the internet only.

The learning material delivered to the class is different, and there needs adaptable content to meet the learning process needs. The learning process in class is face-to-face. Unfortunately, COVID -19 hit the world, forcing the learning process performed with a remote system. The learning process in class is certainly very different from the implementation of distance lectures. Teacher creativity in providing material, the learning process is not just for lecturers to provide material in lecture materials such as books and assignments, but materials can also study the material independently. One alternative medium during the learning/lecturing process at home or distance is a video-based tutorial.

The COVID 19 disaster has forced the world of education to continue to carry out the learning process at home, where teachers and students do not meet face-to-face. Learning that is carried out at home certainly reduces teacher dominance. When the teacher is absent for some reason and cannot teach online, students are expected to still learn by downloading digital material in video tutorials and studying the material independently. The use of video-based material is an essential tool in the educational process. Today's young generation prefers visual-oriented learning media and does not like reading textbooks. In this era of the Industrial Revolution 4.0, information is text and in the form of videos, animations, and images, so the world of education must adjust to these developments. Teachers not only teach in class but must be able to make video-based jar materials. With the support of multimedia-based applications, nowadays, teachers should be able to develop video-based tutorials [1]

Many applications can be used in developing video-based tutorials. One of the applications that are easy to use is Camtasia Studio. Camtasia Studio software is a useful application to create and develop videos, both for video tutorials and film editing. The Camtasia application can record activities carried out on a computer screen, both the entire monitor screen and only part of it. The screen recordings can be saved in video format. Another ability of Camtasia is recording via a camera on a computer. [2]. Using Camtasia Studio is very easy, and the final result is a video, and the result is effortless to use [3]

The research conducted by Fauzan [4] produced a product in the form of video-based learning media with material for making helical gears in Milling Machining Theory. The research result is a product in the form of videos and given to students. The students evaluated the video product, 
INTENSIF, Vol.5 No.2 August 2021

ISSN: 2580-409X (Print) / 2549-6824 (Online)

DOI: https://doi.org/10.29407/intensif.v5i2.15348

and the conclusions from the video were worthy of use and could be used as a medium in assisting the learning process. Yana's research [5] resulted in media used in learning and based on interactive video tutorials. This learning video is used in 2-dimensional animation engineering subjects and sub-frame animation techniques. This learning material is used for class XI of the Multimedia Study Program at Kopang 1 Public Vocational High School. The video material developed is in the form of an application and is packaged in .exe files and interactive C.D.s. Based on the questionnaire given to students, the development of this instructional media video is suitable for use in the learning process.

Pujawan's research [6] resulted in developing teaching materials for the Multimedia I (graphic design) course based on interactive multimedia. The development of this teaching material is used in students' learning process in the Ganesha Polytechnic Informatics Management study program. The research aims to create an interactive multimedia blueprint based on video tutorials.

Hidayat developed Edmodo-based learning for the computer programming course in the Mathematics Education study program at Pekalongan University in his conducted research. The results of the application's evaluation were carried out by giving questionnaires to students. The results obtained on average showed that $81 \%$ of students responded positively to the use of electronic media in the learning process [7]. Other studies that examine video-based learning include [8], [9], [10], [11], [12],[13].

Research using Camtasia Studio as an application development material has already been conducted in several studies. Rahmad [14] conducted research using the Camtasia Studio 8.5 application and produced learning media in video tutorials to support learning in Geography Information Systems (GIS) courses at the Department of Geography Education, Faculty of Social Sciences, Medan State University. The student then evaluates the video tutorial using the questioner.

As a result, students gave a good response category. It shows that video development is good and gets a positive response from students. Fitriasari's research [15] intends to know student learning outcomes use handout media using Camtasia studio. The application of handouts in numerical method courses, especially non-traditional equations. The research subjects were students of the Mathematics education study program FKIP PGRI Palembang University, especially class V.A in the even semester of the 2017/2018 school year. The research results are based on the results of data analysis on the average student learning outcomes using video-based handouts with good categories. Other references from research that develop video-based teaching materials using Camtasia Studio include [16], [17], [18],[19], [20],[21]. 
INTENSIF, Vol.5 No.2 August 2021

ISSN: 2580-409X (Print) / 2549-6824 (Online)

DOI: https://doi.org/10.29407/intensif.v5i2.15348

The research was carried out to provide solutions in the teaching and learning process during the global pandemic so that the learning process could be carried out smoothly and adequately. This tutorial media, of course, is undoubtedly used to implement online lectures during the pandemic period. However, it can still be used in the usual lecture conditions section immediately following the last numbered section of the paper.

\section{RESEARCH METHOD}

The research carried out resulted in a product in the form of a video tutorial for a course. The development model used in this module is the ADDIE development model [22], [23]. The ADDIE model consists of 5 stages: Analyze, Design, Development, Implementation, and Evaluation. Figure 1 stages of research with the ADDIE model

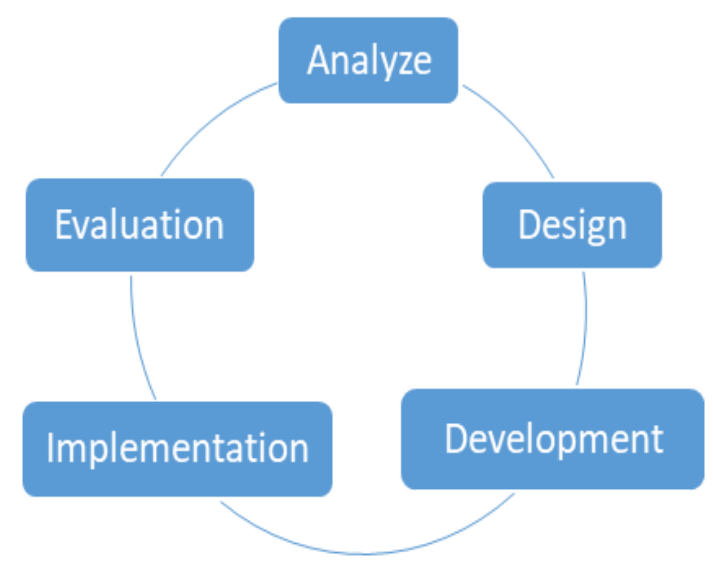

Figure 1. ADDIE RESEARCH MODEL [24]

According to the ADDIE model, the stages carried out in research are (1) at the analysis stage. A needs and strategy analysis were carried out so that lecture material can still be conveyed to students. During the Covid 19 pandemic, there was a sudden change in the lecture process, with students and lecturers conducting lectures online. The problem that exists is changing the habits $t$ in face-to-face lectures and direct interaction with lecturers. For the online lecture process to be effective, it requires material in the form of video tutorials. (2) This design stage is carried out in preparation for making tutorials for learning materials, determining the material, and making a simple description of the video tutorial that would be made. Table 1 is an example of the design of a video tutorial. 
INTENSIF, Vol.5 No.2 August 2021

ISSN: 2580-409X (Print) / 2549-6824 (Online)

DOI: https://doi.org/10.29407/intensif.v5i2.15348

Table 1. ONE OF THE DEVELOPING VIDEO TUTORIAL DESIGNS

\begin{tabular}{|c|c|c|}
\hline No & Gambar & Keterangan \\
\hline 1. & $\begin{array}{l}\text { Tampilkan koding program } \\
x x x x x x x x x x x x x x x \\
x x x x x x x x x x x x x x x x\end{array}$ & $\begin{array}{l}\text { The video will show the } \mathrm{C}++ \text { language editor, the } \\
\text { teacher typing the coding of the examples that will be } \\
\text { discussed. }\end{array}$ \\
\hline 2. & $\begin{array}{l}\text { Suara penjelasan koding } \\
x x x x x x x x x x x x x x x \\
x x x x x x x x x x x x x x x x\end{array}$ & Inserting sound on already displayed coding \\
\hline 3. & $\begin{array}{l}\text { Tampilkan hasil program } \\
x x x x x x x x x x x x x x x x \\
x x x x x x x x x x x x x x x x\end{array}$ & $\begin{array}{l}\text { After the program is run, the next step will display and } \\
\text { run the results of the program created }\end{array}$ \\
\hline
\end{tabular}

(3) The development stage, preparation, and writing of video tutorial material tailored to the needs of students in carrying out the lecture process. At this stage, it begins with making an animation according to the design with the Camtasia Studio application. The initial process of designing the storyline of the animation orderly is illustrated in Figure 2.

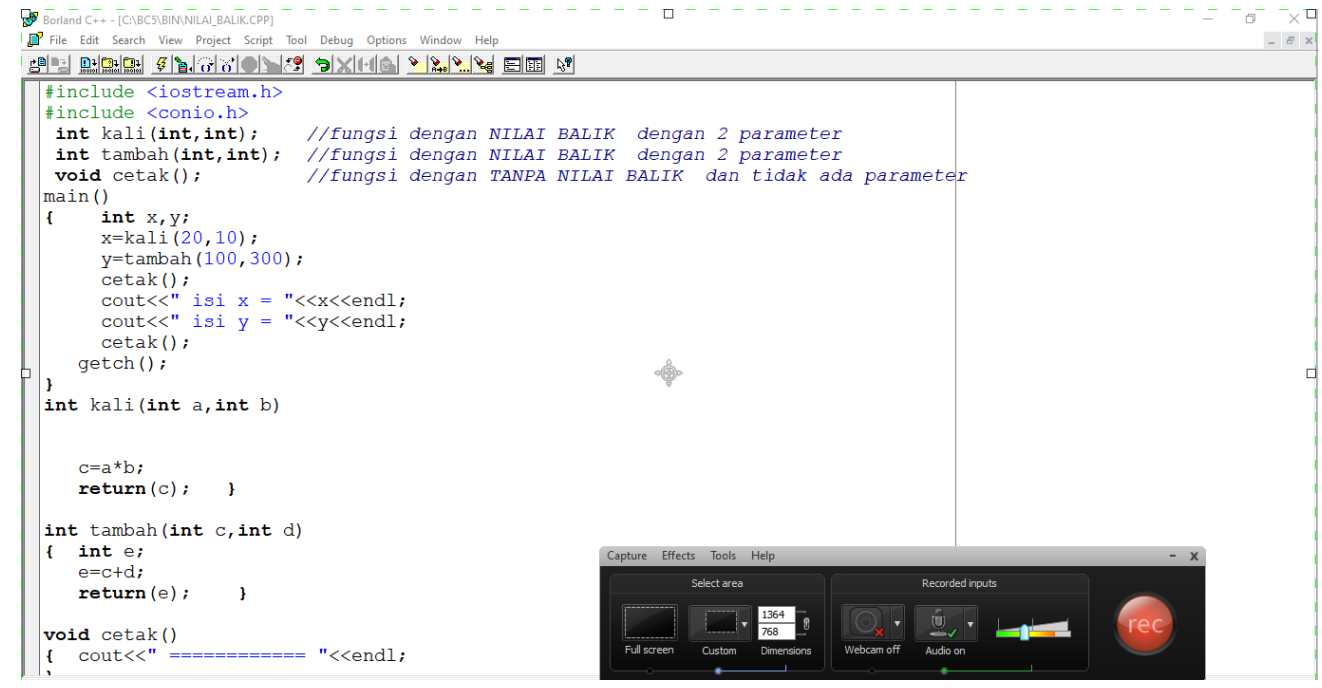

Figure 2. STAGES IN DEVELOPING A VIDEO TUTORIAL

(4) The implementation stage, which uses the development product, resulted in video tutorials. The results of the video tutorial products will be distributed to students using the YouTube channel and existing facilities in the e-learning. (5) The evaluation stage is carried out by providing feedback to students about the benefits of having tutorials in videos.

Research stages are in Figure 2. Figure 2 illustrates the stages of research using the ADDIE model. 
INTENSIF, Vol.5 No.2 August 2021

ISSN: 2580-409X (Print) / 2549-6824 (Online)

DOI: https://doi.org/10.29407/intensif.v5i2.15348

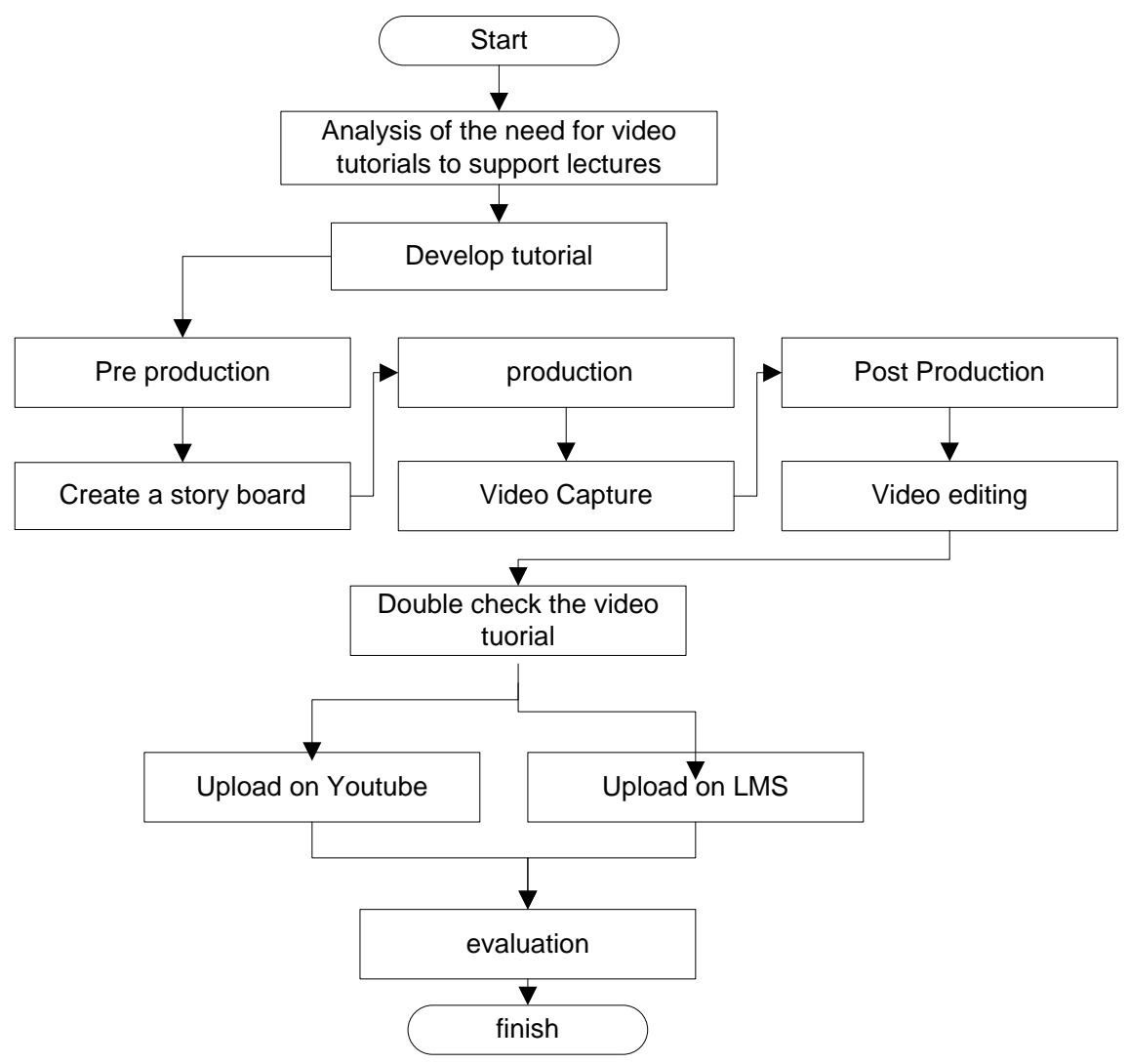

Figure 3. RESEARCH FLOWCHART

\section{RESULT AND DISCUSSION}

A. Video distribution on YouTube

The developed video tutorial resulted in 35 videos. Researchers upload the videos on YouTube with the link bit.ly/2AC5JrV so that students can access them easily. Figure 4 Video material that has been uploaded on YouTube

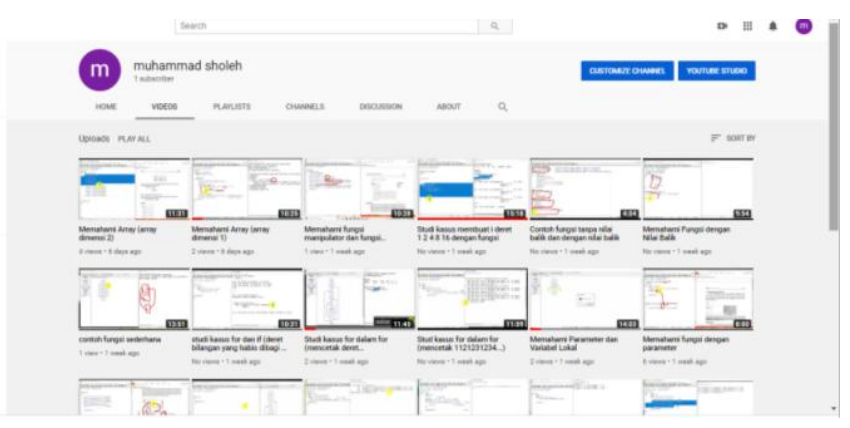

Figure 4. VIDEO MATERIAL THAT HAS BEEN UPLOADED ON YOUTUBE 
INTENSIF, Vol.5 No.2 August 2021

ISSN: 2580-409X (Print) / 2549-6824 (Online)

DOI: https://doi.org/10.29407/intensif.v5i2.15348

B. Video distribution in e-learning

The distribution of videos uploaded on YouTube is only video files and other material in pdf files or other announcement processes such as assignments and submitting assignments using existing e-learning facilities. The e-learning link is on the lms.akprind.ac.id page, and to enter the material, choose a structured programming course. Figure 5 Display of material in lms.akprind.ac.id

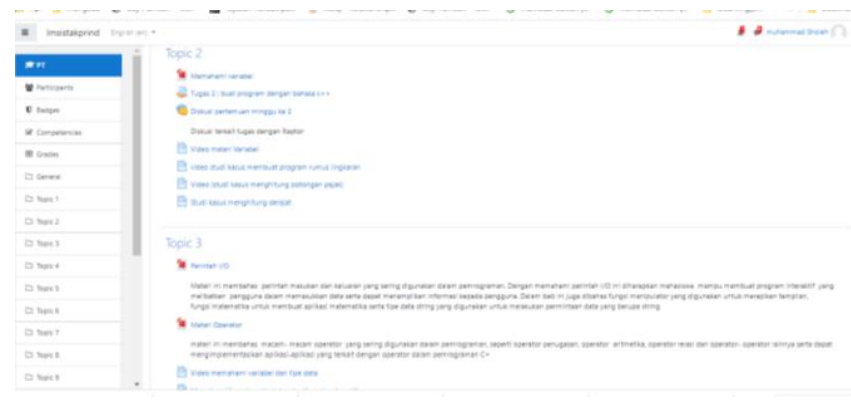

Figure 5. DISPLAY OF MATERIAL IN LMS.AKPRIND.AC.ID

\section{Video Result Display}

As in the pre-production stage, each video start screen displayed a welcome screen that explains the discussed material in the video. Figure 6 shows one of the opening views in the video that discusses the function and identity of the lecturer.

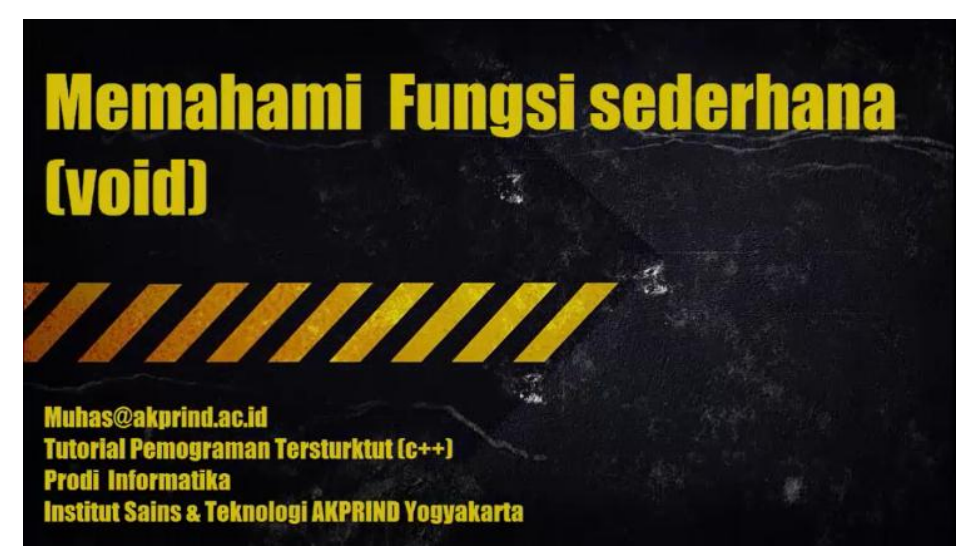

Figure 6. DISPLAY OF THE OPENING PAGE ON THE VIDEO WITH THE FUNCTION MATERIAL

The following video explained the discussed material. Each discussion is equipped with a voice narrative that explains each stage of the coding example. The discussion is also carried out by opening the book in the form of a pdf file and explaining it in scribbles so that it seems like an explanation using a blackboard or display on the LCD screen. Figure 7 explains the video a program flow equipped with sound and discussion of theories-figure 8 Explanation of the material by making doodles. 
INTENSIF, Vol.5 No.2 August 2021

ISSN: 2580-409X (Print) / 2549-6824 (Online)

DOI: https://doi.org/10.29407/intensif.v5i2.15348

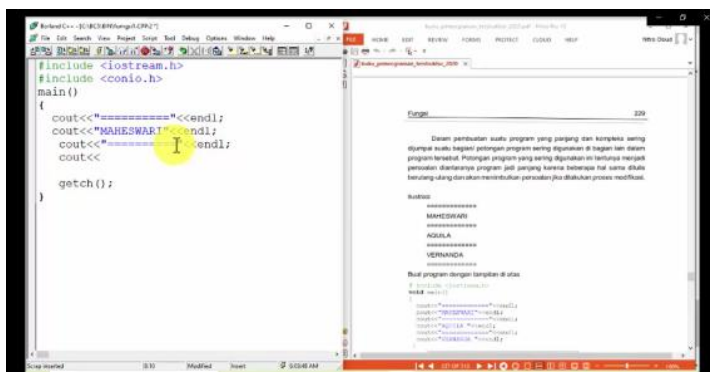

Figure 7. EXPLAINS THE MATERIAL IN THE VIDEO EXPLAINING THE FLOW OF THE PROGRAM

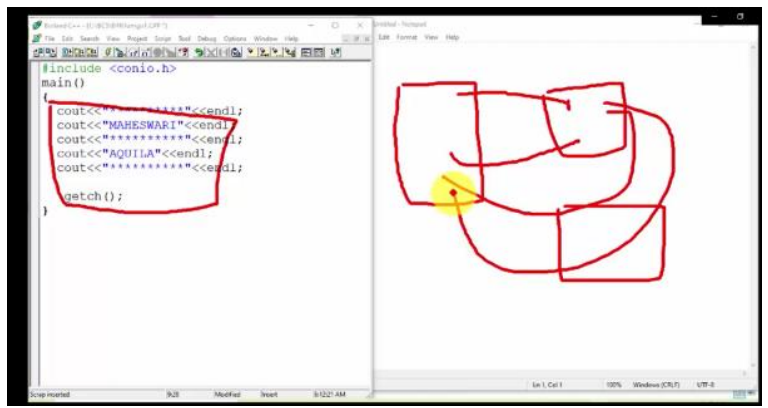

Figure 8. EXPLAINS THE MATERIAL IN THE VIDEO BY MAKING ILLUSTRATIONS

The final result of this video tutorial is to present a discussion of the results of coding. Like explaining the material, explaining the coding results is also equipped with a voice explaining the program's results. At the end of each video, it closes with a closing display in the form of a "thank you" slide. Figure 9 displays the current program results, and Figure 10 shows the closing slide

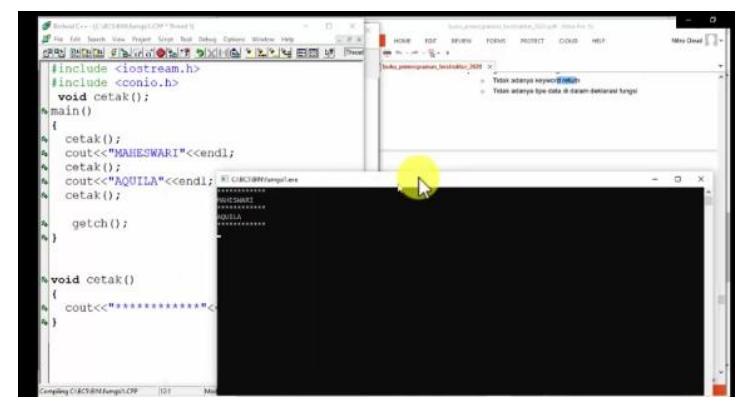

Figure 9. DISPLAYS THE CURRENT PROGRAM

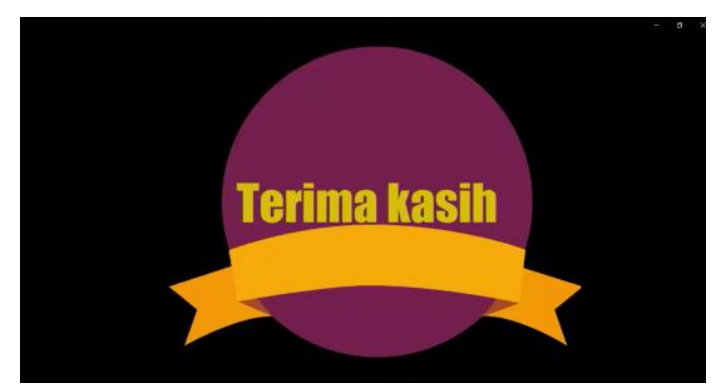

Figure 10. SHOWS THE CLOSING SLIDE 
INTENSIF, Vol.5 No.2 August 2021

ISSN: 2580-409X (Print) / 2549-6824 (Online)

DOI: https://doi.org/10.29407/intensif.v5i2.15348

D. Evaluation of the results of the student questionnaire

The results of the development of this video tutorial are, of course, students who can assess and feel positive or negative benefits. Researchers provided a questionnaire to see student responses. The questionnaire was developed by referring to several questionnaires that several researchers have developed. The questionnaire used as a reference is a questionnaire that asks the use of video to support the learning process. Some of the questionnaire comparisons were conducted by Rahmad [14]. Questionnaires were given by filling in the link bit.ly/3dTKXCb. Of the 30 students who actively participated in the recovery, 24 filled out the questionnaire. The results of the questionnaire included:

1. The instructional videos that the researchers developed provide good material on programming. Respondents' results are shown in figure 11.

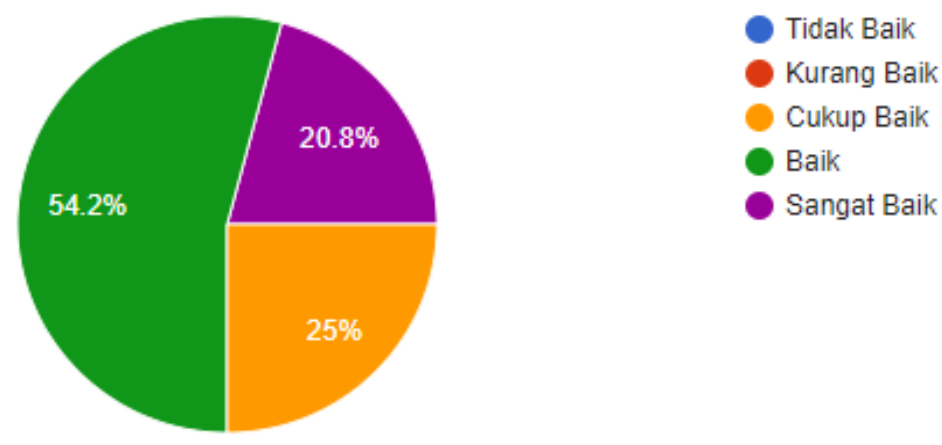

Figure 11. RESPONDENTS' RESULTS ON THE QUESTION OF WHETHER TO PROVIDE GOOD MATERIAL ABOUT PROGRAMMING

2. This learning video can be used for self-study at home. Respondents' results are shown in figure 12.

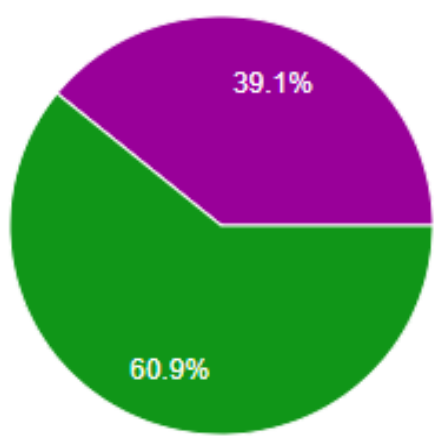

Tidak Baik

Kurang Baik

Cukup Baik

Baik

Sangat Baik

Figure 12. THE RESULTS OF THE RESPONDENTS IN THE QUESTIONS ARE USED FOR SELF-STUDY AT HOME 
INTENSIF, Vol.5 No.2 August 2021

ISSN: 2580-409X (Print) / 2549-6824 (Online)

DOI: https://doi.org/10.29407/intensif.v5i2.15348

3. The explanations and tutorials in the video are clear and easy to understand. Respondents' results are shown in figure 13.

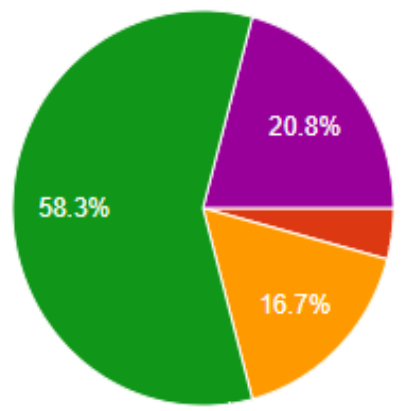

Tidak Baik

Kurang Baik

Cukup Baik

Baik

Sangat Baik

Figure 13. THE RESULTS OF THE RESPONDENTS ON THE TUTORIAL QUESTIONS IN THE VIDEO ARE EASY TO UNDERSTAND

4. The material presented is in good language so that students are easy to understand. Respondents' results are shown in figure 14.

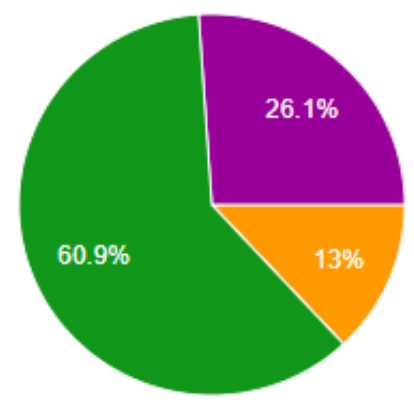

- Tidak Baik

Kurang Baik

Cukup Baik

- Baik

Sangat Baik

Figure 14. RESPONDENTS’ RESULTS ON MATERIAL QUESTIONS USING GOOD LANGUAGE

\section{CONCLUSION}

Amid the Covid-19 pandemic that impacts the lecture process that is not carried out in class, it is necessary to have media to provide lecture materials. Giving material to students is not just material in text such as PowerPoint, Word, or pdf. Of course, these materials will cause a lack of understanding from students in studying the course material, especially programming courses. Programming courses can be given material in the form of text. It needs an explanation to explain programming logic. The solution for the learning process is to make video tutorials that can record screen displays and explanations in the form of sound. In overcoming the problem and simplifying the learning process of Structured Programming courses, 37 videos have been developed. They have been distributed both through YouTube, e-learning facilities, and WhatsApp groups for Structured Programming courses. The evaluation of video learning is done 
INTENSIF, Vol.5 No.2 August 2021

ISSN: 2580-409X (Print) / 2549-6824 (Online)

DOI: https://doi.org/10.29407/intensif.v5i2.15348

by giving a questionnaire to students. One of the questionnaire questions given was whether this learning video could be used for self-study at home. From these questions, 39.1\% of students answered very well, and 60.9 students answered well. This video tutorial is only a complement to the learning process. Lectures were still carried out online using various media such as discussions via WhatsApp groups, face-to-face using Zoom, and e-learning facilities. The use of this video tutorial is not only limited to the Covid-19 pandemic but must still be used in the lecture process in class. With the video tutorials developed by the lecturers themselves, it is hoped that it makes it easier for students to understand the material.

\section{REFERENCES}

[1] T. Limbong and J. Simarmata, Media dan Multimedia Pembelajaran, Teori \& Praktik. Jakarta: Yayasan Kita Menulis, 2020.

[2] Arista Prasetyo Adi, Bikin Video Apapun tanpa Ribet. Jakarta: PT Elex Media Komputindo, 2017.

[3] Jubilee, Membuat Video Tutorial Menggunakan Camtasia. Jakarta: PT Elex Media Komputindo, 2016.

[4] M. A. Fauzan and D. Rahdiyanta, "Pengembangan Media Pembelajaran Berbasis Video pada Teori Pemesinan Frais," Jurnal Dinamika Vokasional Teknik Mesin, vol. 2, no. 2, p. 82, 2017, doi: 10.21831/dinamika.v2i2.15994.

[5] B. A. I. W. Yana, Y. N. Kholisho, and A. Fathoni, "PENGEMBANGAN MEDIA PEMBELAJARAN BERBASIS VIDEO TUTORIAL INTERAKTIF PADA MATA PELAJARAN TEKNIK ANIMASI 2 DIMENSI," EDUMATIC: Jurnal Pendidikan Informatika, vol. 2, no. 2, pp. 52-58, 2018.

[6] K. A. H. Pujawan, "Pengembangan Multimedia Interaktif Berbasis Video Tutorial Pada Mata Kuliah Multimedia I (Design Grafis) Di Politeknik Ganesha Guru," Journal of Education Technology, vol. 2, no. 1, p. 61, 2019, doi: 10.23887/jet.v2i1.13810.

[7] N. Hidayah, S. Karimah, and R. Utami, "Analisis Respon Mahasiswa Terhadap Media Prmbelajaran Berbasis Edmodo pada Mata Kuliah Pemrograman Komputer," Jurnal ilmiah Pendidikan Matematika, vol. 6, no. 1, pp. 17-20, 2018.

[8] S. Mulyono et al., "Perancangan Video Tutorial Audio Dalam Mata Kuliah Audio Visual Simpulan," Jurnal Desain Komunikasi Visual Adiwarna, p. 6, 2017.

[9] A. Y. Utomo and D. Ratnawati, "Pengembangan Video Tutorial Dalam Pembelajaran Sistem Pengapian Di Smk," Taman Vokasi, vol. 6, no. 1, p. 68, 2018, doi: 10.30738/jtvok.v6i1.2839.

[10] A. Efendi, S. Sumarni, and A. Efendi, "PENGEMBANGAN MEDIA PEMBELAJARAN BERBASIS VIDEO TUTORIAL PADA MATA KULIAH MEKANIKA TANAH," Indonesian Journal of Civil Engineering Education, vol. 1, no. 1, pp. 1-12, 2015.

[11] A. Agustiningsih, "Video Sebagai Alternatif Media Pembelajaran Dalam Rangka Mendukung Keberhasilan Penerapan Kurikulum 2013 di Sekolah Dasar," PEDAGOGIA: Jurnal Pendidikan, vol. 4, no. 1, p. 50, 2015, doi: 10.21070/pedagogia.v4i1.72.

[12] S. Bakhri, "Animasi Interaktif Pembelajaran Huruf dan Angka Menggunakan Model ADDIE," INTENSIF: Jurnal Ilmiah Penelitian dan Penerapan Teknologi Sistem Informasi, vol. 3, no. 2, p. 130, 2019, doi: 10.29407/intensif.v3i2.12666.

[13] P. Riegler et al., "Using Tutorials in Introductory Physics on circuits in a German university course: Observations and experiences," Physics Education, vol. 51, no. 6, 
2016, DOI: 10.1088/0031-9120/51/6/065014.

[14] R. Rahmad, E. Yuniastuti, and M. A. Wirda, "PENGEMBANGAN MEDIA PEMBELAJARAN VIDEO TUTORIAL MENGGUNAKAN CAMTASIA STUDIO 8 . 5 PADA MATAKULIAH SISTEM INFORMASI GEOGRAFI (SIG)," Jurnal Ilmiah Pendidikan dan Pembelajaran PPs Universitas Pendidikan Ganesha, vol. 2, no. April 2018, pp. 97-110, 2018.

[15] P. Fitriasari, "Penggunaan Media Handout Berbantuan Camtasia Studio Terhadap Hasil Belajar Mahasiswa pada Mata Kuliah Metode Numerik," Jurnal Pendidikan Matematika RAFA, vol. 4, no. 2, pp. 92-104, 2020, doi: 10.19109/jpmrafa.v4i2.2896.

[16] R. Ariaji, Nasirsah, and S. A. Siregar1, "Pengembangan Video Pembelajaran Kimia SMA/MA Menggunakan Camtasia Studio 8," EKSAKTA :JurnalPenelitian dan Pembelajaran MIPA, vol. 5, no. 1, pp. 55-64, 2020.

[17] D. A. Harahap et al., "PELATIHAN PENINGKATAN KEMAMPUAN GURU DENGAN BERBASIS TIK ( E-MODUL SERTA CAMTASIA VIDEO ) DI SMAN 2," Jurnal Anadara Pengabdian Kepada Masyarakat, vol. 1, no. 2, 2019.

[18] S. Alang Ciputra, "PENGEMBANGAN MEDIA PEMBELAJARAN CAMTASIA STUDIO TERHADAP HASIL PENGEMBANGAN MEDIA PEMBELAJARAN CAMTASIA STUDIO TERHADAP HASIL BELAJAR MATA KULIAH CAD MAHASISWA PENDIDIKAN TEKNIK OTOMOTIF UNIVERSITAS MUHAMMADIYAH PURWOREJO," Jurnal Pendidikan Teknik Otomotif_Universitas Muhammadiyah Purworejo, vol. 10, no. 01, pp. 37-42, 2017.

[19] M. I. Putra, K. U. Ariawan, and I. W. Sutaya, "PENGEMBANGAN MEDIA PEMBELAJARAN BERBASIS CAMTASIA STUDIO VIDEO CD INTERAKTIF MULTIMEDIA UNTUK MATA PELAJARAN PEMROGRAMAN WEB DI JURUSAN MULTIMEDIA SMK NEGERI 3 SINGARAJA,” Jurnal Pendidikan Teknik Elektro Undiksha, vol. 6, no. 1, pp. 1-8, 2017.

[20] Rizmada Azzahra, "Analisis Pembuatan Video Media Pembelajaran dalam Mata Kuliah Pembelajaran Menyimak 0leh Mahasiswa Kelas A Semester V Prodi Pendidikan Bahasa Indonesia Universitas Khairun Ternate," Widyabastra, vol. 05, no. 1, pp. 8-14, 2017.

[21] S. Sukmawati, T. F. Saumi, and A. Nasrullah, "Camtasia-assisted computer statistics application practicum learning video in online classes to improve students' mathematical understanding," Journal of Physics: Conference Series, vol. 1657, no. 1, 2020, DOI: 10.1088/1742-6596/1657/1/012016.

[22] A. A. Agama and M. Solikin, "Development of tutorial video learning media on engine management system diagnosis," Journal of Physics: Conference Series, vol. 1700, no. 1, 2020, DOI: 10.1088/1742-6596/1700/1/012057.

[23] Zainuddin, A. R. Hasanah, M. A. Salam, Misbah, and S. Mahtari, "Developing the interactive multimedia in physics learning," in Journal of Physics: Conference Series, 2019, vol. 1171, no. 1, DOI: 10.1088/1742-6596/1171/1/012019.

[24] Y. H. Rayanto and Sugianti, PENELITIAN PENGEMBANGAN MODEL ADDIE DAN R2D2. Pasuruan: Lembaga Academic \& Research Institute, 2020. 